\title{
The Effect of Teacher's Code Switching on Vocabulary Acquisition of Senior High School Students: EFL Learners
}

\author{
${ }^{1}$ M. Sofian Hadi, ${ }^{2}$ Lidyatul Izzah, ${ }^{3}$ Via Rahmawati \\ Email: ${ }^{1}$ m_sofianhadi@yahoo.com, ${ }^{2}$ idyatulizzah@gmail.com, ${ }^{3}$ vrahmawati79@gmail.com \\ 1, 2, 3 Universitas Muhammadiyah Jakarta, Indonesia
}

\section{ARTICLE INFO}

Article history

Received: 25 February 2021

Revised: 9 March 2021

Accepted: 10 March 2021

Keywords

code switching

EFL learners

vocabulary

\section{ABSTRACT}

This research is aimed at finding and describing the effect of teacher's code-switching on vocabulary acquisition of senior high students: EFL Learners the eleven grade students at MAN 2 LEBAK in the academic year of 2020/2021. This research was conducted from January to February 2021. This research was classified as a pre-experimental study. It involved 25 students from one class. The pre-test was given to the participants before the treatment and the post-test was given after the treatment. The data of the pre-test and post- test of the participants were analyzed by using descriptive and inferential statistics. After the data were tested and found the hypothesis $\left(\mathrm{H}_{1}\right)$ was accepted and the null hypothesis $\left(\mathrm{H}_{0}\right)$ was rejected. The result of the research shows that the difference in the mean score between the students' score pre-test and post-test. the score was 7,2, which obtained in the degree of freedom (df) of 23, with the degree of significance 5\%, it gained score 1,71387. Which means the t-observation was higher than t-table. It showed that teacher's code-switching on Students' vocabulary acquisition is effective.

\section{Introduction}

In teaching of English as a Foreign Language (EFL) process, teachers and learners inevitably participate in various situations involving the use of L1. The debate about the good and bad of code switching in the educational environment has caused controversy. To a certain extent, many people belief that code switching will be helpful for educators and learners to achieve learning goals, while for some people, the use of code switching is only an obstacle.

Code switching (CS) is a language phenomenon that occurs in multilingual voice communities. This term describes the process by which multilingual speakers with communication skills usually switch or switch between two languages or multiple languages or codes in the same conversation (Iyad, 2016). 
Types of CS have been divided into three categorized varieties of CS into three classes namely tag switching, inter-sentential switching and intra-sentential switching (Jingxia, 2010: 11). Tagswitching, in which tags and certain set phrases in one language are inserted into an utterance otherwise in another. Inter-sentential switching, in which a change of language occurs at sentence levels, where each clause or sentence is in one language or the other. Intra-sentential switching, in which switches occur within a clause or sentence boundary. It can take the form such as, code changing, code mixing, insertion and congruent lexicalizations

Usually code switching found in teaching process. Nordin, et al. (2012: 483) Establish communication between the teacher and the student or otherwise is carried out through language, because at the same time an interruption occurs, and code switching choosen to overcome these obstacles.

In Indonesia, in a classroom environment where teachers and students share their mother tongue, many studies show that in EFL classrooms, teachers use CS (Kustati, 2014; Nurhayati, 2014; Widia, 2015; Fatimah 2016; Fhitri, 2017). Studies have shown that teachers use CS in the teaching for several excuse. The major excuse is to promote students' learning, because by using CS teachers believe that they can improve students' understanding of textbooks (Widia, 2015: 16) and provide students with understandable input, especially for lower grade students (Fatima, 2016) : 73). Kustati (2014: 181)'s research also shows that when teachers use CS, classroom participation is improved because students have a better understanding of instructions.

In addition, research on teachers using CS in EFL classes in the language environment shows that people are worried that excessive in using CS in the class have a negative impact on the teaching process. Teachers also worry that students may become accustomed to CS, and finally will reduce students' willingness to speak in English (Kustati, 2014: 174). Fhitri (2017: 3) shows the use of Code switching by teachers in the classroom is not a solution that teachers can use for promoting learning. Basically, teachers use code switching because they are influenced by students' mother tongue, which is considered of interference when teachers use L2 (Fhitri, 2017: 9). Sakaria and Priyana (2018: 176) said that excessive use of CS in EFL classroom can make the students over-reliance. The students encourage teachers to use CS carefully to promote learning. Therefore, code switching has many benefits to the EFL classroom, one of them is to promote learning, but its should be noted in its use, it could be a sign that the teacher has insufficient proficiency in L2 and should be cautious.

Even if CS is an inseparable part of second language teaching, there should be instructions for conducting CS in the classroom. The standard criteria of teaching in the classroom are: (a) the language balance should be 50/50; (b) the language change should be subconscious; and (c) the 
rotation is for teaching and learning purposes (Noli, Maishara Nordin et al : 2012). Regarding the positive and negative aspects of transcoding, you should know the reasons of it. The mastery grade of learners has become the cause of the problem. Students prefer to replace or switch languages because the language skill they have are not sufficient, nor is it equal to the proficiency of their teacher (Üstunel, 2016: 45). Students should find a convenient way to communicate with classmates. They do not use English as a spoken language, otherwise they use their mother tongue or language. From the other hand, teachers can take code switching actions to resolve the gaps in the dialogue. Like code-switching, an unprecedented level of teachers and students should be filled in some way. This is an obstacle.

The resolution to choose vocabulary as the target of language learning is notably based on some research on code switching. The result of the research explains that the use of code switching in the classroom indicate that one of the functions of code switching is to explain L2 vocabulary, Teachers seem to intuitively feel that teacher CS is very valuable in L2 vocabulary teaching. According to the understanding of Nation (2011) and others, the acquisition of vocabulary is significant for achieving the success in using of a second language and have an substantial role in oral and written texts. Vocabulary becomes the basis for acquiring or learning the target language.

\section{Method}

The researchers used quantitative research. According to Matthews \& Ross as cited in Goertzen (2017: 12) quantitative research methods are concerned with collecting and analyzing data that is structured and can be represented numerically. The researchers also used preexperimental focusing on one group pre-test and post-test design in this study. Pre-experimental design is a simplest design which implicate of a single group and there is no random assignment to the subjects to the experimental group. According to Ary (2010:328) Pre-experimental provides little or no control of extraneous variables. It means that used single group and used pre-test and post-test. There are three types of instruments used to collect the data that should be accurate. In this study, the researchers conducted eight meetings by online using WhatsApp application.

\section{Pre-test}

Pre-Test is conducted to measure how understand the students about vocabulary acquisition to the target words. The pre-test was done in the first meeting before the participant given the treatment. The researchers using google docs in conducting the pre-test, the kind of test used by the researchers is VKS (vocabulary knowledge scale) there were twenty questions given regarding targeted vocabulary. 


\section{Treatment}

The researchers created materials or a lesson plans adapted to the school curriculum of participant. After creating, the material which has been adjusted with the participant school, the material that taught in this research is analytical exposition text. Then in the second meeting the researchers explain about analytical exposition text (definition and purpose of code-switching) with implementing code switching in the classroom when teaching and learning process. The third meeting the researchers explain the structure of analytical exposition text with conducting code-switching. The fourth meeting the researchers give the example of text from analytical exposition text. The fifth meeting the students should read aloud the text that has given before, it is were doing in order to students can understand the text well. In the sixth meeting the researchers explain the text that were given to the students. Then in the seventh meeting the students given the opportunity to ask about the material overall. And during teaching and learning process the researchers try to avoid use of code switching excessively, because it can decrease the willingness of the students to speak English.

\section{Post-test}

Post-test is conducted to measure and find out the significant after the treatment of teacher's code-switching. The post-test is held by using Google Docs. And using the VKS (vocabulary knowledge scale) type of test and some question about analytical exposition text.

\section{Data Analysis}

There is a single group in this study. The researchers use one class. The treatment is taught vocabulary acquisition by using teachers' code-switching. Before that the researchers will give them the pre-test to measure the existing lexical knowledge about vocabularies. In the end, the researchers gave them post-test to measure if there is significant change after the treatment.

a. Determining t-test

$$
t=\frac{X 1-X 2}{\sqrt{\left(\frac{S S 1+S S 2}{N 1+N 2-2}\right)\left(\frac{1}{N 1}+\frac{1}{N 2}\right)}}
$$

Where:

t $\quad$ : Test of Significance

2 : The number of test involved

1 : Constant number

b. Determining Degree of Freedom

$$
\mathrm{Df}=\mathrm{N}-2
$$




\section{Discussion}

The data of this study was collected from XI IPA 2 students of MAN 2 LEBAK in academic year of $2020 / 2021$. The total of this study is 25 students.

The data needed in this study was collected by three instruments. They were pre-test, treatment, post-test. The pre-test was conducted on February 9th, 2021 in order to get their existing linguistic knowledge about vocabulary. The treatment was conducted on February $12^{\text {th }}-$ $20^{\text {th }} 2021$ in order to review or improve their linguistic knowledge about vocabulary through code-switching. The post-test was conducted on February 23 ${ }^{\text {rd }}, 2021$ in order to find out the significance progress after the treatment. The result of the data were described in the following:

Table 1. Pre-test and post-test analysis

\begin{tabular}{|c|c|c|c|c|c|}
\hline No. & Name & $\begin{array}{c}\text { Post-test } \\
\text { (X1) }\end{array}$ & $\begin{array}{c}X 1 \\
\text { Kuadrat }\end{array}$ & $\begin{array}{c}\text { Pre-test } \\
(X 2)\end{array}$ & $\begin{array}{c}\text { X2 } \\
\text { Kuadrat }\end{array}$ \\
\hline 1 & Participant 1 & 85 & 7255 & 50 & 2500 \\
\hline 2 & Participant 2 & 90 & 8100 & 65 & 4225 \\
\hline 3 & Participant 3 & 90 & 8100 & 70 & 4900 \\
\hline 4 & Participant 4 & 90 & 8100 & 60 & 3600 \\
\hline 5 & Participant 5 & 95 & 9025 & 70 & 4900 \\
\hline 6 & Participant 6 & 75 & 5625 & 55 & 3025 \\
\hline 7 & Participant 7 & 95 & 9025 & 75 & 5625 \\
\hline 8 & Participant 8 & 90 & 8100 & 50 & 2500 \\
\hline 9 & Participant 9 & 55 & 3025 & 50 & 2500 \\
\hline 10 & Participant 10 & 95 & 9025 & 40 & 1600 \\
\hline 11 & Participant 11 & 95 & 9025 & 50 & 2500 \\
\hline 12 & Participant 12 & 90 & 8100 & 45 & 2025 \\
\hline 13 & Participant 13 & 95 & 9025 & 60 & 3600 \\
\hline 14 & Participant 14 & 75 & 5625 & 65 & 4225 \\
\hline 15 & Participant 15 & 90 & 8100 & 55 & 3025 \\
\hline 16 & Participant 16 & 70 & 4900 & 25 & 625 \\
\hline 17 & Participant 17 & 70 & 4900 & 45 & 2025 \\
\hline 18 & Participant 18 & 95 & 9025 & 50 & 2500 \\
\hline 19 & Participant 19 & 75 & 5625 & 60 & 3600 \\
\hline 20 & Participant 20 & 65 & 4225 & 30 & 900 \\
\hline 21 & Participant 21 & 80 & 6400 & 65 & 4225 \\
\hline 22 & Participant 22 & 90 & 8100 & 75 & 5625 \\
\hline 23 & Participant 23 & 85 & 7225 & 45 & 2025 \\
\hline 24 & Participant 24 & 80 & 6400 & 55 & 3025 \\
\hline 25 & Participant 25 & 55 & 3025 & 30 & 900 \\
\hline & TOTAL & $\begin{array}{l}\sum \mathrm{X}_{1}= \\
2065\end{array}$ & $\begin{array}{c}\sum \mathrm{X}_{1}^{2}= \\
175080\end{array}$ & $\begin{array}{l}\sum \mathrm{X}_{2}= \\
1330\end{array}$ & $\begin{array}{l}\sum X_{2}^{2}= \\
76200\end{array}$ \\
\hline
\end{tabular}

From the table 1.2, it can be seen that the result is $\Sigma X_{1}=2065, \Sigma X_{1}{ }^{2}=175080$ and $\Sigma X_{2}=$ 1330, $\Sigma X_{2}{ }^{2}=76200$. The analysis of the post-test (X1) and pre-test (X2) variable as follows:

1. Determining Mean of $\mathrm{X}_{1}$ Variables

$$
M 1=\frac{\sum \mathrm{X} 1}{\mathrm{~N} 1}=\frac{2065}{25}=82,6
$$


2. Determining of Standard Deviation Score of X1 Variables

$$
\begin{aligned}
& S D_{1}=\sqrt{\frac{S S_{1}}{N_{1}-1}} \text { where } S S_{1}=\sum X 1^{2}-\frac{(\Sigma X 1)^{2}}{N 1} \\
& S S_{1}=175080-\frac{(2065)^{2}}{25} \\
& S S_{1}=175080-170569 \\
& S S_{1}=4511 \\
& S D_{1}=\frac{\sqrt{4511}}{24} \\
& S D_{1}=\sqrt{187}, 9 \\
& S D_{1}=13,7
\end{aligned}
$$

3. Determining Mean of X2 Variables

$$
M 2=\frac{\sum \times 2}{\mathrm{~N} 1}=\frac{1330}{25}=53,2
$$

4. Determining of Standard Deviation Score of X2 Variables

$$
\begin{aligned}
& S D_{2}=\sqrt{\frac{S S_{2}}{N_{2}-1}} \text { where } S S_{2}=\sum X 2^{2}-\frac{\left(\sum X 2\right)^{2}}{N 2} \\
& S S_{2}=76200-\frac{(1330)^{2}}{25} \\
& S S_{2}=76200-70756 \\
& S S_{2}=5444 \\
& S D_{2}=\frac{\sqrt{544} 4}{24} \\
& S D_{2}=\sqrt{22,68} \\
& S D_{2}=4,77
\end{aligned}
$$

\section{Determining t-test}

$$
\begin{aligned}
& t=\frac{X 1-X 2}{\sqrt{\left(\frac{S S 1+S S 2}{N 1+N 2-2}\right)\left(\frac{1}{N 1}+\frac{1}{N 2}\right)}} \\
& \mathrm{t}=\frac{82,6-53,2}{\sqrt{\frac{(4511+5444)}{25+25}}\left(\frac{1+}{25} \frac{1}{25}\right)} \\
& \mathrm{t}=\frac{29,4}{\frac{\sqrt{9955}}{48}}\left(\frac{2}{25}\right) \\
& \mathrm{t}=\frac{29,4}{\sqrt{2074 x} 0,08} \\
& \mathrm{t}=\frac{29,4}{\sqrt{16,5}} \\
& \mathrm{t}=\frac{29,4}{4,1} \\
& \mathrm{t}=7,2
\end{aligned}
$$

6. Determining Degree of Freedom

$$
\mathrm{df}=\mathrm{N}-2
$$




$$
\begin{aligned}
& \mathrm{df}=25-2=23 \\
& \mathrm{df}=23
\end{aligned}
$$

\section{Determining t-table in Significant Level 5\% with Degree of Freedom.}

The value of $\mathrm{df}$ is 23 at degres of significance $5 \%$ or t-table is 1,71387 . The result of the data that has been analyzed proved that Teachers' Code-Switching On Students' Vocabulary Acquisiton is effective.

Table 2

\begin{tabular}{|c|c|c|}
\hline t-calculation & t-table & Significant \\
\hline 7,2 & 1,71387 & Significant \\
\hline
\end{tabular}

After calculating the data to the $\mathrm{T}$ score, the $\mathrm{T}$ test was found to be greater than the $\mathrm{T}$ table. This means that teachers' code-switching has a significant impact on students' vocabulary acquisition. Therefore, the research hypothesis (H1) is accepted, and the null hypothesis (H0) is rejected.

In the previous subtitle, the author has used statistical formulas to analyze the data of this study. Through statistical analysis and analysis of the data of Class XI IPA 2 students, it is found that the mean scores before and after the test are different. Mean before the test was 53.2 and mean after the test was 82.3. In fact, it is obvious that Class of XI IPA 2 has different performance between score pre-test and post-test. As mentioned earlier, the average score before the test was 53.2, and the average score after the test was 82.3. Mean score after the treatment is higher than the mean score before the treatment. It shows that the performance of students after treatment is better than before treatment. And according to previous studies into teacher's code switching in the classroom indicate that one of the functions of code switching is to explain L2 vocabulary. Also refers to Jacobson's view that when the teacher uses code switching, the language distribution must be 50/50, meaning that it is balanced between the mother tongue and the target language. this will motivate students to try to speak in the target language.

However, the author needs to use statistical procedures to prove the hypothesis to see if there is any significant impact. In this case, the author uses the t-test formula to get 7,2 points. In this study, the author wants to know whether the $\mathrm{T}$ count is greater than the $\mathrm{T}$ table in 23 degrees of freedom, with a significance level of 0,05 , which is 1,7138 . Therefore, based on the above calculation results, the author finds that $T$-count $\geq T$-table $(7,2 \geq 1,71387)$. The author statistically proves that teachers' code-switching has a significant impact on students' vocabulary acquisition. 


\section{Conclusion}

Based on the study that was conducted in XI IPA 2 of students at MAN 2 LEBAK, Banten. Although this study was conducted by online and used WhatsApp application to collect the data, the study was running well. First impression of students while the teacher using code-switching they were amazed because the teacher usually using almost Indonesian language while teaching.

The first thing the researchers did was determine the target word and adjust to the lesson plan from the English book, it is about analytical exposition text. Then the researchers select the theme Global Warming, is it an end to our world? The reading text is adjusted to books that are in accordance with the applicable curriculum in the participant's school, so that they can understand easily and the targeted vocabulary also adjusted to that book. Then because this study was being held during pandemic covid-19, the researchers use the audio as the media, and lastly immediate post-test which measure the acquisition of vocabulary knowledge.

It can be seen and concluded that there are differences result between mean score pre-test and post-test, it is proven from the result that is obtained. Pre-test is obtaining 53,2 and post-test is 82,6 . From the explanation above, there is a significant result by using Teacher's CodeSwitching. In addition, by using code switching, students can understand instructions better (Kustati, 2014: 181), also can improve the students understanding to learning material taught by the teacher, especially on the textbook (Widia, 2015: 16). And lastly, code-switching can establish the communication between teachers and the students (Nordin, Ali, Zubir \& Sadjirin, 2012: 483).

\section{References}

Ary, D., Jacobs, L.C., Sorensen, C., Razavieh, A. (2010). Introduction to research in education (8th edi.). Canada. Nelson Education, Ltd.

Fatimah, D. N. (2016). Why is there code switching in efl classroom? : A case study in a vocational school in Cimahi, West-Java. Jurnal Pendidikan Bahasa dan Sastra, 16(1), 70-77

Fhitri, W. (2017). Code switching used by English lecturers during teaching as found in Padang State University. Jurnal Arbitrer, 4(1), 1-9.

Iyad, Ahmad. (2016). Code switching as a linguistics phenomenon among Palestinian English Arabic billinguals with reference to translation.

Jingxia, L. (2010). Teachers' code-switching to the L1 in EFL classroom. The Open Applied Linguistic Journal, 3(10), 10-23. Retrieved from: https://benthamopen.com/ contents/pdf/TOALJ/TOALJ-3-10.pdf

Kustati, M. (2016). An analysis of code-mixing and code-switching in EFL teaching of crosscultural communication context. Research Gate. 21(3). 174-182. 
Matthews, B. and Ross, L. (2010). Research Methods: A Ppractical guide for the social sciences, University of Leeds.

Melissa, J. Goertzen (2017). Library of technology report (vol. 53, no.4), Appliying quantitative methods to e-book collection.

Nation, I. S. P (2011). Learning vocabulary in another language. Cambridge: Cambridge University Press.

Noli. Maishara Nurdin, et al (2012). ESL Learners' reaction towards code-switching in classroom setting. Procedia - Social and Behavioral Sciences 90 (2013) 478-487.

Nordin, N. M., Ali, F. D. R., Zubir, S. I. S. S., \& Sadjirin, R. (2013). ESL learners' reactions towards codeswitching in classroom setting. Procedia-Social and Behavioral Sciences, 90, 478- 487. https://doi.org/10.1016/j.sbspro.2013.07.117

Nurhayati, S. R. (2014). Teacher's code-switching to L1 in an English as a Foreign Language classroom in a senior high school in Banten. Paper presented in 61st TEFLIN International Conference. Retrieved May 3, 2018.

Sakaria, S., Priyana, J. (2018). Code-switching: A pedagogical strategy in Bilingual classrooms. American Journal of Educational Research, 6(3), 175-180.

Üstunel, E. (2016). EFL classroom code-switching. Turkey: Palgrave Macmillan.

Widia, A. R., (2014). Code switching for English language teaching and learning in EFL classroom. Jurnal Ilmiah Teknologi dan Informasia ASIA (JITIKA), 9(2), 15-17. 